Received 09/20/2021

Review began 11/18/2021

Review ended 12/05/2021

Published 12/30/2021

๑) Copyright 2021

Anas Sohail et al. This is an open access article distributed under the terms of the Creative Commons Attribution License CC BY 4.0., which permits unrestricted use, distribution, and reproduction in any medium, provided the original author and source are credited.

\section{The Cognitive-Enhancing Outcomes of Caffeine and L-theanine: A Systematic Review}

Anas Anas Sohail ${ }^{1}$, Fernando Ortiz ${ }^{2}$, Teresa Varghese ${ }^{3}$, Stephanie P. Fabara ${ }^{4}$, Arshdeep S. Batth ${ }^{5}$, Darshan P. Sandesara ${ }^{6}$, Ahtesham Sabir ${ }^{7}$, Mahika Khurana ${ }^{8}$, Shae Datta ${ }^{9}$, Urvish K. Patel ${ }^{10}$

1. Medicine, Aureus University School Of Medicine, Oranjestad, ABW 2. Neurology, Larkin Community Hospital, Miami, USA 3. Medicine, Kasturba Medical College, Manipal University, Manipal, IND 4. General Medicine, Universidad Catolica de Santiago de Guayaquil, Guayaquil, ECU 5. Infectious Disease, University of Louisville, Louisville, USA 6. Cardiology, Apex Heart Institute, Ahmedabad, IND 7. Internal Medicine, Ayub Medical College, Abbottabad, PAK 8. Public Health, University of California Berkeley, Berkeley, USA 9. Neurology, NYU Langone Health, New York, USA 10. Public Health and Neurology, Icahn School of Medicine at Mount Sinai, New York, USA

Corresponding author: Fernando Ortiz, sumjuanfer41@gmail.com

\section{Abstract}

Attention-deficit hyperactivity disorder (ADHD) affects multiple cognitive domains, including impaired attention, hyperactivity, and increased impulsivity. According to the CDC, 9.4\% of children between 2 and 17 years old have been diagnosed with ADHD. Neurotransmitters such as noradrenaline and dopamine have been suggested as crucial players in the pathophysiology of ADHD and are often targets of modern medication. Adenosine receptors types $\mathrm{A} 1$ and $\mathrm{A} 2 \mathrm{a}$ in the brain are inhibited by caffeine: a stimulant known to augment attention by increasing cholinergic and dopaminergic transmission. The cognitive function of attention is also enhanced by the amino acid: L-theanine. The mechanism of action is that it behaves like a glutamate reuptake inhibitor while also acting in the hippocampus as a competitive low-affinity glutamate receptor antagonist. It's also shown to have a neuroprotective effect by its action on the gamma aminobutyric acid (GABA)-A receptors. Our systematic review investigates the literature and clinical trials on the cognitive-enhancing effects of caffeine and L-theanine.

Categories: Internal Medicine, Neurology, Integrative/Complementary Medicine

Keywords: caffeine, green tea, adhd, mental cognition, memory reconsolidation, I-theanine, I-theanine and caffeine, matcha

\section{Introduction And Background}

L-theanine is an amino acid found notably in green tea, black tea, and some mushrooms. It is known for enhancing cognitive function, particularly attention [1]. L-theanine has a few mechanisms of action. First, it is a glutamate reuptake inhibitor. Second, in the hippocampus, it is a competitive low-affinity glutamate receptor antagonist [2]. Third, it acts on the gamma aminobutyric acid (GABA)-A receptors conferring a protective effect for neurons [3]. Caffeine is a stimulant found primarily in tea, coffee, and cacao plants. Its mechanism of action includes inhibition of adenosine receptors, types $\mathrm{A} 1$ and $\mathrm{A} 2 \mathrm{a}$ in the brain, which then increases cholinergic and dopaminergic transmissions, thus augmenting attention [4].

Attention-deficit hyperactivity disorder (ADHD) affects multiple cognitive domains. Patients have hindered attention, increased activity, and often act before thinking first. Combining these deficits have shed light on ADHD as a function of improper inhibitory control [5]. This systematic review will explore the impacts of Ltheanine, caffeine, and particularly the combined effects of these substances on managing cognitive deficits associated with ADHD.

\section{Review}

\section{Methods}

Protocol

Our systematic review complied with the Preferred Reporting Items for Systematic Reviews and MetaAnalysis (PRISMA) [6].

Criteria for Eligibility and Selection of Studies

Clinical trials conducted in the last 20 years were included in our review. The same criteria were used for observational studies. The findings of these studies were published in English. All other trials and studies except the ones aforementioned were excluded. Next, redundant studies in which the outcome was not appropriate to our objective were removed.

The studies we looked at compared patients to a control group which factored in outcomes such as 


\section{Cureus}

attention enhancement, cognitive improvement, and/or ADHD.

Database and Search Strategy

PubMed was our database source. The CDC states that $9.4 \%$ of children between 2 and 17 years old have been diagnosed with ADHD [7]. Our search was conducted between 06/07/2021- 06/30/2021. We used the following search terms and their combinations: "L theanine caffeine"[Title/Abstract] OR "theanine caffeine"[Title/Abstract] OR ("Matcha"[All Fields] AND "caffeine"[Title/Abstract].

A search of MEDLINE and Scopus did not provide any additional clinical trials for this review.

Data Extraction

Author and year of publication, methodology, and functional outcomes were collected. These studies provided the number of participants in the treatment group, the number of participants in the control group, the dose, the route of drug administration, the treatment duration, and the timing of when the drugs were given after the onset of symptoms. Modified Rankin Scale (mRS) and National Institutes of Health Stroke Scale (NIHSS) scores, Barthel Index (BI), and overall mortality are included in the baseline functional outcomes. Table 1 includes our methods summary.

\begin{tabular}{|c|c|}
\hline Key Terms & Database \\
\hline “L theanine caffeine”[Title/Abstract] & PubMed \\
\hline “Theanine caffeine”[Title/Abstract] & PubMed \\
\hline “Matcha”[All Fields] AND “caffeine"[Title/Abstract] & PubMed \\
\hline
\end{tabular}

TABLE 1: Methods summary

Assessment of Biases

For clinical trials, we detected biases using the Cochrane collaboration's risk of bias tool[8]. For observational studies, we used the Risk Of Bias In Non-randomized Studies--of Interventions (ROBINS-I) tool [9]. Figure 1 uses the PRISMA flowchart to exhibit study results. 


\section{Cureus}

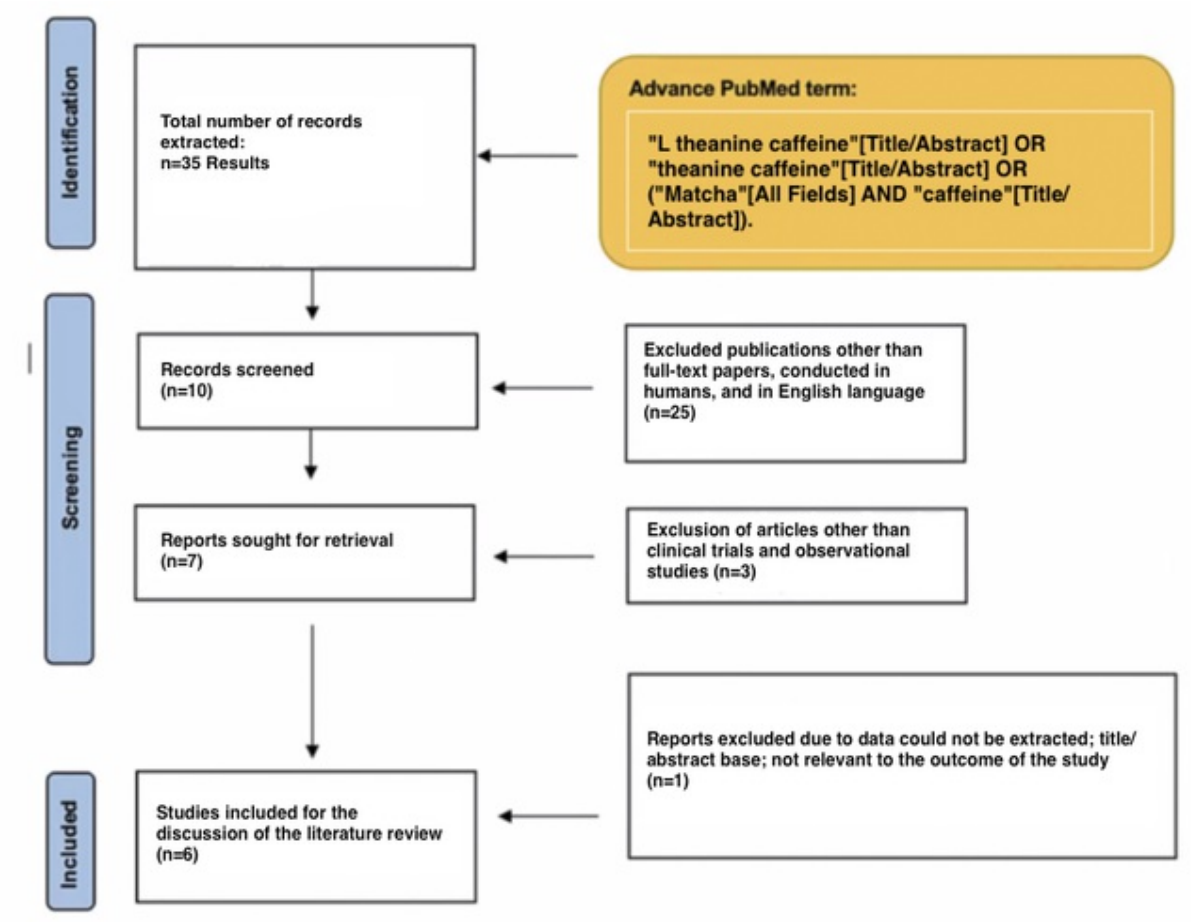

\section{FIGURE 1: Preferred Reporting Items for Systematic Reviews and Meta-Analysis (PRISMA) flowchart}

\section{Results}

These clinical trials measured one or more of the following parameters: cognition, reaction times, concentration, and/or others measure including headaches, tiredness, or alertness. Specifically, the tests used by one or more of these studies include NIH Cognition Toolbox, stop-signal reaction time (used to check control of inhibition), total cognition composite, d-prime in the Go/NoGo task, fMRI responses, mean recognition visual reaction time (RVRT), amplitudes of the mean peak-to-peak N2-P300 event-related potential (ERP), "headache" ratings, "tired" ratings, "alert" ratings, digit vigilance reaction time, correct serial seven subtractions, rapid visual information processing (RVIP) accuracy, and word recognition reaction time.

The 2020 study from Kahathuduwa et al. explored acute outcomes of L-theanine, caffeine, and their combined effects on maintained attention, control on inhibition, and general cognition in the five boys diagnosed with ADHD [10]. Improvements by the L-theanine-caffeine combination were shown on impairments related to ADHD, meaning it may be a potential therapeutic consideration. Total cognition composite was improved with L-theanine in the NIH Cognition Toolbox $(p=0.040)$ vs placebo. Inhibitory control was worsened by caffeine, and L-theanine, separately, as suggested by longer reaction times seen in the stop-signal intervention ( $p=0.031$ and $p=0.053$, respectively). Whereas, improvement in cognition was seen in the total cognition composite $(p=0.041)$, and in the Go/NoGo task $(p=0.033)$. Improvements in control of inhibition $(p=0.080)$ was also apparent. The combination was also associated with decreased task-related reactivity in the default mode network of the brain in the region associated with mind-wandering, which meant decreased distractibility and improved concentration.

The 2018 study by Kahathuduwa et al. investigated the outcomes of $200 \mathrm{mg}$ of L-theanine, $160 \mathrm{mg}$ of caffeine, a fusion of the two, and distilled water in a four-way crossover study design using nine healthy adult men [11]. A visual color stimulus discrimination task was performed by the subjects, where an fMRI scan was performed for 20 minutes, 60 minutes after administering L-theanine, caffeine, and their combination. The fMRI results confirmed a decrease in mind-wandering by showing fewer responses to distractor stimuli in regions of the brain where visual attention is regulated. It was also observed that $\mathrm{L}$ theanine decreases GABA levels and caffeine increases glutamate levels. This leads to the visible patterns of blood oxygenation level dependent (BOLD) responses which were seen with L-theanine alone and when combined with caffeine.

The 2017 study by Kahathuduwa et al. investigated the impact of $200 \mathrm{mg}$ of L-theanine, and $160 \mathrm{mg}$ of caffeine, the combination of both, a single cup of black tea, and distilled water in a five-way crossover trial with 20 healthy adult males [12]. Participants took a dose of L-theanine, which was analogous to drinking eight cups of black tea; these effects are comparable to that of caffeine. Several measurements were assessed, as mentioned in Table 2, which demonstrated an improvement in the subject's cognitive and 


\begin{tabular}{|c|c|c|c|c|c|}
\hline $\begin{array}{l}\text { Author, } \\
\text { year, } \\
\text { country }\end{array}$ & Study type & Population & Study design & Intervention & Outcome \\
\hline $\begin{array}{l}\text { Kahathuduwa, } \\
2020 \text { [10] }\end{array}$ & $\begin{array}{l}\text { Single- } \\
\text { blinded, } \\
\text { randomized } \\
\text { placebo- } \\
\text { controlled } \\
\text { trial }\end{array}$ & $\begin{array}{l}\text { Patients with } \\
\text { ADHD } \\
\text { compared to } \\
\text { placebo. Five } \\
\text { males } \\
\text { between } 8 \text { and } \\
15 \text { years. }\end{array}$ & $\begin{array}{l}\text { Participants stop } \\
\text { caffeine and } \\
\text { stimulants } 24 \text { hours } \\
\text { before. Participants } \\
\text { were evaluated using } \\
\text { continuous } \\
\text { performance tasks } \\
\text { (“Go/NoGo”) and a } \\
\text { stop-signal task in four } \\
\text { laptops visits for } 10 \\
\text { minutes. Functional } \\
\text { MRI was performed } \\
\text { during the tests }\end{array}$ & $\begin{array}{l}\text { L-theanine } \\
(2.5 \mathrm{mg} / \mathrm{kg}) \\
\text { and caffeine } \\
(2 \mathrm{mg} / \mathrm{kg}) \\
\text { fusion. To } \\
\text { evaluate NIH } \\
\text { Cognition } \\
\text { Toolbox }\end{array}$ & 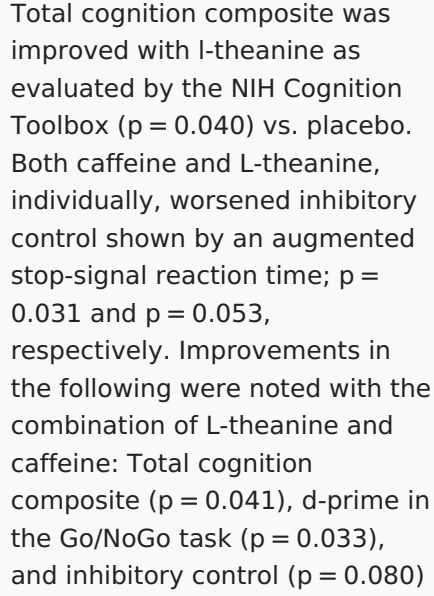 \\
\hline $\begin{array}{l}\text { Kahathuduwa, } \\
2018 \text { [11] }\end{array}$ & $\begin{array}{l}\text { Randomized } \\
\text { control trial } \\
\text { using a four- } \\
\text { way } \\
\text { crossover } \\
\text { design }\end{array}$ & $\begin{array}{l}\text { Nine healthy } \\
\text { adult men }\end{array}$ & $\begin{array}{l}\text { A visual color stimulus } \\
\text { discrimination task } \\
\text { was performed by } \\
\text { subjects using four } \\
\text { different } \\
\text { interventions. } \\
\text { Meanwhile, an fMRI } \\
\text { scan was performed } \\
\text { for } 20 \text { minutes }\end{array}$ & $\begin{array}{l}\text { Using a } \\
\text { randomized } \\
\text { four-way } \\
\text { crossover, L- } \\
\text { theanine, } \\
\text { caffeine ( } 200 \\
\text { and } 160 \mathrm{mg} \text {, } \\
\text { respectively), } \\
\text { a fusion of } \\
\text { the two, and } \\
\text { distilled } \\
\text { water were } \\
\text { administered } \\
\text { accordingly. } \\
\text { Distilled } \\
\text { water } \\
\text { represents a } \\
\text { placebo }\end{array}$ & $\begin{array}{l}\text { Response time to targets were } \\
\text { quicker versus placebo } \\
\text { (difference of } 27.8 \mathrm{~ms}, \mathrm{p}=0.018 \\
\text { and difference of } 26.7 \mathrm{~ms} \text {, } \\
\mathrm{p}=0.037 \text {, respectively) were } \\
\text { assessed with L-theanine and L- } \\
\text { theanine-caffeine combination. } \\
\text { Fewer fMRI signals to distractive } \\
\text { stimuli in the brain were noted in } \\
\text { subjects on L-theanine, where } \\
\text { visual attention is regulated. } \\
\text { Decreased fMRI responses to } \\
\text { target stimuli were also assessed } \\
\text { with the L-theanine-caffeine } \\
\text { combination, showing a } \\
\text { synergistic action in decreasing } \\
\text { mind-wandering }\end{array}$ \\
\hline $\begin{array}{l}\text { Kahathuduwa, } \\
2017 \text { [12] }\end{array}$ & $\begin{array}{l}\text { A placebo- } \\
\text { controlled, } \\
\text { five-way } \\
\text { crossover } \\
\text { trial }\end{array}$ & $\begin{array}{l}\text { Twenty } \\
\text { healthy males }\end{array}$ & $\begin{array}{l}\text { The effects of each } \\
\text { intervention were } \\
\text { compared with } \\
\text { cognitive and } \\
\text { neurophysiological } \\
\text { measures of attention. } \\
\text { Cognitive measures } \\
\text { include simple visual } \\
\text { reaction time (SVRT) } \\
\text { and recognition visual } \\
\text { reaction time (RVRT). } \\
\text { Neurophysiological } \\
\text { measures include } \\
\text { event-related } \\
\text { potentials (ERPs). } \\
\text { Treatment outcomes } \\
\text { on visual (peripheral) } \\
\text { and motor conduction } \\
\text { were examined using } \\
\text { the visual evoked } \\
\text { potentials (VEPs) and } \\
\text { motor evoked } \\
\text { potentials (MEPs), }\end{array}$ & $\begin{array}{l}\text { L-theanine } \\
\text { ( } 200 \text { mg), } \\
\text { caffeine ( } 160 \\
\text { mg), the } \\
\text { combination } \\
\text { of the two, a } \\
\text { single cup of } \\
\text { black tea, } \\
\text { and distilled } \\
\text { water were } \\
\text { administered } \\
\text { accordingly. } \\
\text { Distilled } \\
\text { water } \\
\text { represents a } \\
\text { placebo }\end{array}$ & $\begin{array}{l}\text { Significant improvement of mean } \\
\text { RVRT was measured: } L \text {-theanine } \\
\text { ( } p=0.019 \text { ), caffeine ( } p= \\
0.043) \text {, and L-theanine-caffeine } \\
\text { fusion ( } p=0.001 \text { ). However, this } \\
\text { was not the case with the } \\
\text { following: Tea ( } p=0.429 \text { ) or } \\
\text { distilled water ( } p=0.822 \text { ). } \\
\text { Larger, and more significant } \\
\text { mean peak-to-peak N2-P300 ERP } \\
\text { were elicited by L-theanine ( } p= \\
0.001 \text { ) and caffeine ( } p=0.001 \text { ) } \\
\text { compared to placebo, whereas a } \\
\text { significantly larger mean N2- } \\
\text { P300 amplitude was recorded for } \\
\text { the L-theanine-caffeine } \\
\text { combination compared to } \\
\text { placebo ( } p<0.001 \text { ), L-theanine } \\
\text { ( } p=0.029 \text { ), or caffeine ( } p= \\
0.005 \text { ) }\end{array}$ \\
\hline
\end{tabular}




\section{Cureus}

\begin{tabular}{|c|c|c|c|c|c|}
\hline & & & respectively. & & \\
\hline $\begin{array}{l}\text { Haskell, } 2008 \\
\text { [13] }\end{array}$ & $\begin{array}{l}\text { Randomized, } \\
\text { placebo- } \\
\text { controlled, } \\
\text { double-blind, } \\
\text { balanced } \\
\text { crossover }\end{array}$ & $\begin{array}{l}\text { Twenty-four } \\
\text { participants } \\
\text { completed the } \\
\text { experiment ( } 9 \\
\text { male and } 15 \\
\text { female, mean } \\
\text { age } 21.3 \\
\text { years, S.E.M. } \\
0.83, \text { range } \\
\text { 18-34 years). } \\
\text { Participants } \\
\text { abstained } \\
\text { from caffeine } \\
\text { and alcohol for } \\
\text { a minimum of } \\
12 \text { hours } \\
\text { before the first } \\
\text { testing session } \\
\text { and } \\
\text { throughout the } \\
\text { morning until } \\
\text { the final } \\
\text { testing session } \\
\text { was completed }\end{array}$ & $\begin{array}{l}\text { The acute cognitive } \\
\text { and mood effects of } \\
\text { the interventions were } \\
\text { investigated in this } \\
\text { study. Salivary } \\
\text { caffeine levels were } \\
\text { co-monitored }\end{array}$ & $\begin{array}{l}\text { L-theanine, } \\
\text { and caffeine } \\
\text { ( } 250 \text { and } 150 \\
\text { milligrams, } \\
\text { respectively) } \\
\text { were } \\
\text { administered } \\
\text { both } \\
\text { individually, } \\
\text { and } \\
\text { combined }\end{array}$ & $\begin{array}{l}\text { Augmented ratings for } \\
\text { "headache" and fewer correct } \\
\text { serial seven subtractions were } \\
\text { noted in subjects taking L- } \\
\text { theanine. Greater accuracy in } \\
\text { rapid visual information } \\
\text { processing (RVIP). More reports } \\
\text { of "mental fatigue" were also } \\
\text { assessed in subjects taking L- } \\
\text { Theanine. These subjects also } \\
\text { showed faster digit vigilance } \\
\text { reaction times. Quicker simple } \\
\text { reaction time and quicker } \\
\text { working memory (in terms of } \\
\text { numbers) reaction time, and } \\
\text { better accuracy of sentence } \\
\text { verification were features of the } \\
\text { L-theanine-caffeine combination. } \\
\text { Furthermore, "headache" and } \\
\text { "tired" ratings were reduced and } \\
\text { "alert" ratings increased. A } \\
\text { significantly positive interaction } \\
\text { on delayed word recognition } \\
\text { reaction time was also noted } \\
\text { with L-theanine-caffeine } \\
\text { combination }\end{array}$ \\
\hline $\begin{array}{l}\text { Baba, } 2021 \\
{[14]}\end{array}$ & $\begin{array}{l}\text { Double- } \\
\text { blind, } \\
\text { randomized, } \\
\text { placebo- } \\
\text { controlled, } \\
\text { parallel- } \\
\text { group study }\end{array}$ & $\begin{array}{l}\text { Fifty-one } \\
\text { Japanese men } \\
\text { and women } \\
\text { (all healthy). } \\
\text { Aged } 50 \text { to } 69 \\
\text { years reported } \\
\text { a decline in } \\
\text { cognitive } \\
\text { function. They } \\
\text { also needed } \\
\text { the ability to } \\
\text { take nine } \\
\text { capsules daily } \\
\text { for } 12 \\
\text { consecutive } \\
\text { weeks, while } \\
\text { having an } \\
\text { MMSE-J score } \\
\text { of } 24 \text { or more, } \\
\text { and not be } \\
\text { active } \\
\text { smokers }\end{array}$ & $\begin{array}{l}\text { Single-intake effects } \\
\text { of the interventions, } \\
\text { as well as continuous } \\
\text { intake effects were } \\
\text { compared. Under } \\
\text { stress conditions, the } \\
\text { effectiveness of } \\
\text { continuous intake was } \\
\text { assessed. Stress was } \\
\text { instigated by the use } \\
\text { of the Uchida- } \\
\text { Kraepelin test (UKT). } \\
\text { To assess cognitive } \\
\text { function, the } \\
\text { Cognitrax was } \\
\text { implemented }\end{array}$ & $\begin{array}{l}\text { Nine placebo, } \\
\text { caffeine, or } \\
\text { matcha } \\
\text { capsules } \\
\text { were given to } \\
\text { participants } \\
\text { everyday for } \\
12 \text { weeks } \\
\text { before noon }\end{array}$ & $\begin{array}{l}\text { During stress loading and post- } \\
\text { stress loading, a single caffeine } \\
\text { dose improved attentional } \\
\text { function. Caffeine content found } \\
\text { in matcha may have been the } \\
\text { most likely culprit for slower } \\
\text { reaction time in the Cognitrax. } \\
\text { The amount of work was } \\
\text { increased with continuous } \\
\text { matcha intake. On the other } \\
\text { hand, the group taking caffeine } \\
\text { exhibited more work done for the } \\
\text { UKT after one dose of caffeine. } \\
\text { Work performance and attention } \\
\text { are both improved with ingestion } \\
\text { of matcha with caffeine during } \\
\text { periods of psychological stress } \\
\text { versus caffeine on its own }\end{array}$ \\
\hline
\end{tabular}

\section{TABLE 2: Summary of studies involved in our systematic review}

ADHD: attention-deficit hyperactivity disorder; MRI: magnetic resonance imaging; NIH: National Institutes of Health; fMRI: functional magnetic resonance imaging; SVRT: simple visual reaction time; RVRT: recognition visual reaction time; ERPs: event-related potentials; VEPs: visual evoked; MEPs: motor evoked potentials; RVIP: rapid visual information processing; MMSE-J: mini-mental state examination-Japanese; UKT: Uchida-Kraepelin test

The 2008 study by Haskell et al. investigated the impact of $250 \mathrm{mg}$ of L-theanine, and $150 \mathrm{mg}$ of caffeine, individually, and in combination on the acute cognitive and mood effects in participants [13]. They found higher ratings for headache and lower correct serial seven subtractions in subjects administered L-theanine. Participants provided caffeine were noted to have quicker reaction time for the vigilance of digits, better accuracy for rapid visual information processing (RVIP), and greater reports of mental fatigue. Quicker simple reaction time, quicker working memory (in terms of numbers) reaction time, and better accuracy of 


\section{Cureus}

sentence verification were recorded for participants taking the L-theanine and caffeine fusion. Participants reported a reduction in "headache" and "tired" ratings, while "alert" ratings were increased. Moreover, a significantly positive interaction on delayed word recognition reaction time was noted with the combination.

The 2021 study by Baba et al. evaluated the usefulness of continuous matcha intake (contains L-theanine), caffeine, their combination, and placebo under stress conditions [14]. Mild stress was induced acutely using the Uchida-Kraepelin test (UKT), while the cognitive function was evaluated by using the Cognitrax. The function of attention was improved during and post-stress loading with one caffeine dose. The caffeine content in matcha was reported to likely have caused the lower reactive time seen in the Cognitrax. However, participants continuously taking matcha showed augmented amounts of work like the caffeine group, except the caffeine group did it on a singular dose. Ingestion of the combination of matcha with caffeine improves work performance and attention under psychological stress versus with caffeine on its own.

Limitations

The 2020 study by Kahathuduwa et al. has some limitations[10]. First, it used a small sample size of only five male children with ADHD [10]. This constrains the variance of outcome measures and generalizability to all children. Second, while neuroimaging findings may have been minimally affected, the results of the Go/NoGo test, the stop-signal assignment, and the NIH Cognition Toolbox, which rely on scoring by a person involved in the study, may be influenced by bias due to unblinding [10]. Third, participants were not provided standardized food/beverages or instructions to abstain from food before each visit where they were tested [10]. Their hunger level could impact the outcomes of maintained attention, impulsive behaviors, and results seen on fMRI [15]. These limitations suggest that the preliminary evidence presented needs more power by using a larger sample size in future clinical trials.

The 2018 study by Kahathuduwa et al. was underpowered in sample size making it difficult to capture enough changes in BOLD fMRI responses from certain regions of the brain [11]. Second, only male subjects were selected in this study's sample in order to avoid interferences from the natural changes seen in the menstrual cycle on reaction times in female subjects, thereby limiting the generalizability of this study's findings. Third, it is well understood that caffeine affects cerebral circulation. However, cerebral circulation in human brains is not as well understood with L-theanine. Changes in blood oxygen levels in certain regions of the brain determine responses noted in BOLD fMRI. In this study, it is unclear whether the recorded observations were from true neural responses, or vascular responses which do not depend on neural activation changes.

The 2017 study by Kahathuduwa et al. had technical limitations [12]. Early and late stages of processing related to attention are components of ERP, unlike EEG frequency components. Due to the technical limitations regarding baseline corrections for ERP waveforms, the amplitudes of the individual components could not be measured reliably by the study. Instead, N2-P300 peak-to-peak amplitude was measured by taking the difference between amplitudes of the N2 and the P300 peaks seen on EEG. Another limitation was the duration of reaction time tests, meaning the study was unable to evaluate the performance of the effect that treatment had on sustained attention over longer periods.

The 2008 study by Haskell et al. was limited by a lack of understanding of the mechanisms of action underlying their reported findings [13]. Whether directly or indirectly, caffeine and L-theanine have been shown to affect several neurotransmitter systems including dopamine, serotonin, glutamate, and GABA. However, at the time of their publication, the study claims, the effects of L-theanine and caffeine in combination had not been studied on the level of receptors.

The 2021 study by Baba et al. had limitations including the participants' ages, nationality, and quality of stress [14]. The observed effects were limited to participants that were Japanese. The study selected individuals between the ages of 50 to 69 years old, who drank green tea habitually. Furthermore, the study showed a positive anti-stress effect, but only for continuous calculations of single digits to assess attention and work performance. No quantifiable biomarkers were measured, nor qualitative assessments on how stressed a participant was were performed in this study. Table 3 shows the bias risk tool analysis of each study. 


\section{Cureus}

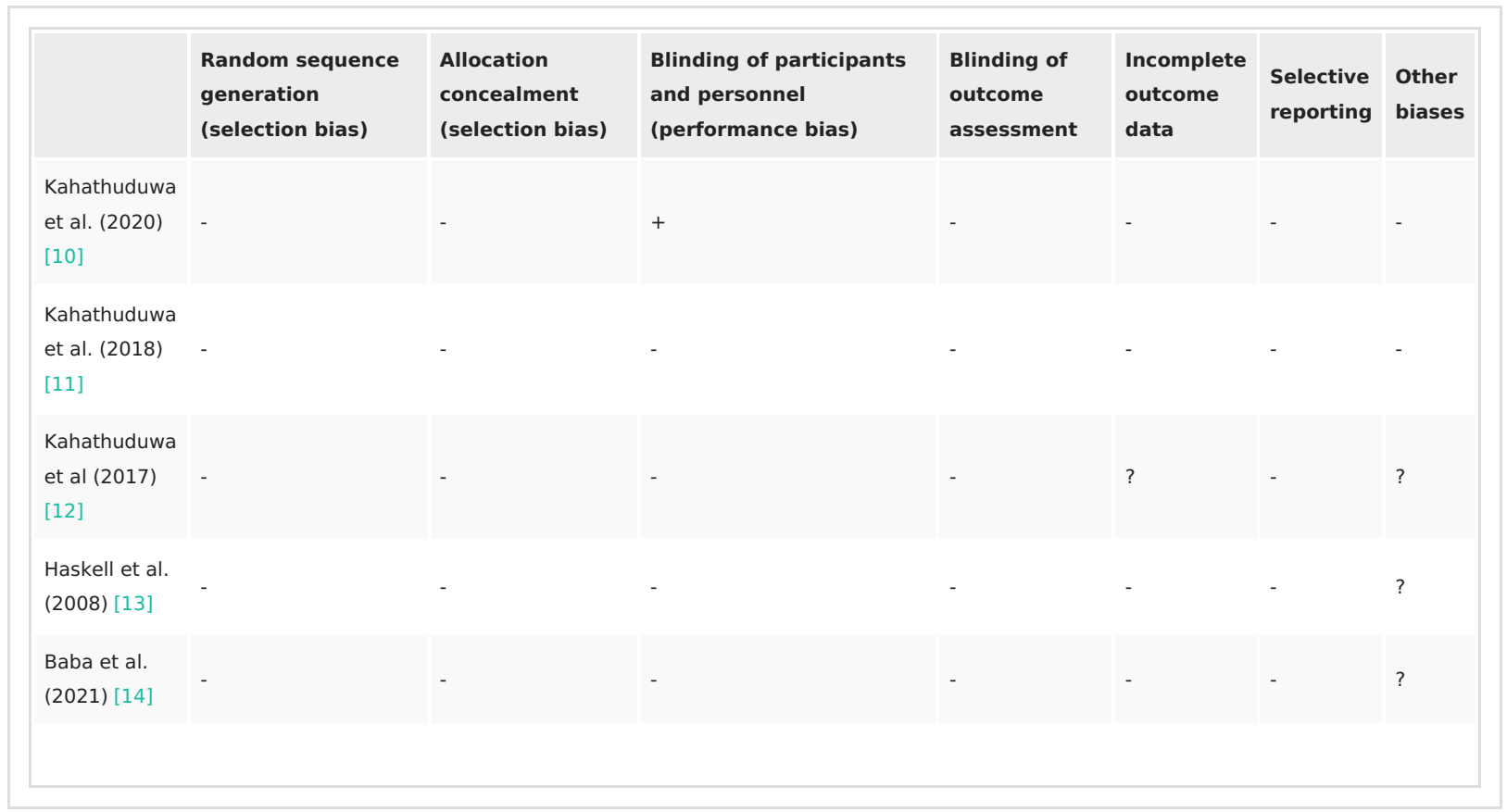

TABLE 3: Shows the bias risk tool analysis of each study

- = Low bias risk

$+=$ High bias risk

$?=$ Unclear bias risk

\section{Discussion}

Overall, these clinical trials of caffeine, L-theanine, and their combination showed various functional outcomes related to attention, inhibitory control, mind-wandering, cognition, and mood [10-14].

The 2020 study from Kahathuduwa et al. showed that participants taking L-theanine demonstrated improvements in total cognition composite as seen using the NIH Cognition Toolbox $(p=0.040)$ compared to placebo [10]. The NIH Cognition Toolbox includes seven cognitive function tests: a flanker inhibitory control and attention test, a picture sequence memory test, a list sorting working memory test, a picture vocabulary test, an oral reading recognition test, dimensional change card sort test, and a pattern comparison processing speed test. On their own, caffeine and L-theanine showed deteriorating control on inhibition: There was an augmented reactive time for the stop-signal test for caffeine $(p=0.031)$ and for L-theanine $(p$ $=0.053)$. However, improvements were noted with inhibitory control $(p=0.080)$; overall cognition composite $(p=0.041)$; and d-prime in the $\mathrm{Go} /$ NoGo assignment $(p=0.033)$ with subjects on the L-theanine-caffeine combination. This suggests that the combination enhances the user's attention, cognition, and inhibitory control, perhaps via synergistic effects. Improvement in these parameters is essential for patients with ADHD, though a larger sample size is needed to increase the power of this study and prove statistical significance.

The 2018 study by Kahathuduwa et al. used fMRI on subjects to observe responses in visual color stimulus discrimination tasks [11]. L-theanine and L-theanine-caffeine fusion resulted in quicker target reactions versus placebo (difference of $27.8 \mathrm{~ms}(p=0.018)$ and $26.7 \mathrm{~ms}(p=0.037)$, respectively). Distractor stimuli in parts of the cerebrum where visual attention is affected showed decreased fMRI responses in participants taking L-theanine. Their results imply that the combination decreases mind-wandering, perhaps by increasing neural resources related to attention toward target stimulus, and lowering neural resources toward distractions. This would explain why the combination helps increase the user's attention on a given task. However, the study also needs a larger sample size, ideally including both men and women. Furthermore, caffeine's effect on cerebral circulation needs to be taken into account before making generalizations about the combination's perceived favorable effects.

The 2017 study by Kahathuduwa et al. showed mean recognition visual reaction time (RVRT) was significantly improved by L-theanine $(p=0.019)$, caffeine $(p=0.043)$, and L-theanine-caffeine combination ( $p$ $=0.001)$, but not by tea $(p=0.429)$ or placebo $(p=0.822)$ [12]. The ERP is a time-locked measure of the electrical activity of the cerebral surface representing a distinct phase of cortical processing. Two components of the ERP which bear special importance to stimulus evaluation, selective attention, and conscious discrimination in humans are the P300 positivity and N200 negativity. Amplitudes of the mean peak-to-peak N2-P300 ERP were significantly larger when elicited with L-theanine $(p=0.001)$ and caffeine 


\section{Cureus}

$(p=0.001)$ versus placebo; whereas a significantly larger mean N2-P300 amplitude was measured with Ltheanine-caffeine combination compared to placebo $(p<0.001)$, L-theanine $(p=0.029)$, or caffeine $(p=$ 0.005). This means visual and motor conduction improved significantly with the combination. However, this approach was limited by its duration of only 10 target trials in each reaction time test. Therefore, the study could not evaluate the effect that treatment had on the performance of sustained attention over a longer period. Further investigation is still needed on the length of sustained attention when taking the L-theaninecaffeine combination.

The 2008 study by Haskell et al. showed higher ratings for headache and lower correct serial seven subtractions in subjects taking L-theanine alone [13]. Whereas improved RVIP accuracy, faster digit vigilance reaction time, and attenuated increases in mental fatigue (self-reported) were noted in subjects taking caffeine alone. Quicker simple reaction time and quicker working memory (in terms of numbers) reaction time, and better accuracy of sentence verification were features of the L-theanine-caffeine combination. Ratings of 'headache' and tiredness were reduced, while ratings of alertness were increased. A significantly positive interaction on the reaction time of delayed word recognition was also measured in participants taking the fusion of L-theanine and caffeine. Although promising, research is still needed to further understand the neurochemical effects of $\mathrm{L}$-theanine and caffeine in combination at the receptor level to better explain these findings.

The 2021 study by Baba et al. showed improved function in attention both during and post-stress loading with a single dose of caffeine [14]. Mild stress was induced using the Uchida-Kraepelin test (UKT), while the function of cognition was evaluated using the Cognitrax. The Cognitrax is an assessment procedure that uses reliable computerized neuropsychological tests to evaluate the neurocognitive status of patients covering a range of mental processes from simple motor performance, attention, memory, to processing speed. The Cognitrax showed reduced reaction times when observing participants that took a single dose of matcha. Matcha's caffeine content may have been the underlying cause for the observation. Participants that continuously took L-theanine (by ingestion of matcha) exhibited more amounts of work completed while UKT was administered, similar to those on a single dose of caffeine. The researchers concluded that there was improved attention and work performance for participants experiencing induced psychological stress when taking matcha in combination with caffeine versus with caffeine alone. However, the results may be skewed as many participants already had a habit of drinking green tea. Furthermore, since no quantifiable biomarkers were measured, nor qualitative assessments to assess a participant's level of perceived stress, further investigation on the combination's effect on stress, performance, attention, memory, and overall cognition is advised.

\section{Conclusions}

Caffeine and L-theanine are natural compounds found primarily in tea and coffee, respectively. The combination has shown improvement in short-term sustained attention and overall cognition. Reversed taskrelated mind-wandering and improved inhibitory control were also seen among boys with ADHD, while improvements in mild acute stress and increased amount of work were noted in the population of men and women aged 50-69 in Japan. After reviewing the studies, we found the combination shows favorable clinical significance in the domains of attention, memory, cognition, and hyperactivity. Overall, we conclude that the combination of L-theanine and caffeine is likely a safe and effective cognitive enhancer. Further research is still needed to explain the aforementioned limitations.

\section{Additional Information \\ Disclosures}

Conflicts of interest: In compliance with the ICMJE uniform disclosure form, all authors declare the following: Payment/services info: All authors have declared that no financial support was received from any organization for the submitted work. Financial relationships: All authors have declared that they have no financial relationships at present or within the previous three years with any organizations that might have an interest in the submitted work. Other relationships: All authors have declared that there are no other relationships or activities that could appear to have influenced the submitted work.

\section{References}

1. Kapalka GM: Nutritional and Herbal Therapies for Children and Adolescents. Practical Resources for the Mental Health Professional. Academic Press, 2010. 10.1016/C2009-0-01890-X

2. Kakuda T, Nozawa A, Sugimoto A, Niino $\mathrm{H}$ : Inhibition by theanine of binding of $[3 \mathrm{H}] A M P A,[3 \mathrm{H}] \mathrm{kainate}$, and [3H]MDL 105,519 to glutamate receptors. Biosci Biotechnol Biochem. 2002, 66:2683-6.10.1271/bbb.66.2683

3. Egashira N, Hayakawa K, Osajima M, Mishima K, Iwasaki K, Oishi R, Fujiwara M:Involvement of GABA(A) receptors in the neuroprotective effect of theanine on focal cerebral ischemia in mice. J Pharmacol Sci. 2007, 105:211-4. 10.1254/jphs.scz070901

4. Camfield DA, Stough C, Farrimond J, Scholey AB: Acute effects of tea constituents L-theanine, caffeine, and epigallocatechin gallate on cognitive function and mood: a systematic review and meta-analysis. Nutr Rev. 2014, 72:507-22. 10.1111/nure.12120

5. Diagnostic and statistical manual of mental disorders: DSM-5 ${ }^{\mathrm{TM}}$ (5th ed.). (2013). Accessed: September 25, 2021: https://psycnet.apa.org/record/2013-14907-000. 


\section{Cureus}

6. Moher D, Liberati A, Tetzlaff J, Altman DG, the PRISMA Group: Preferred reporting items for systematic reviews and meta-analyses: the PRISMA statement. PLoS Med. 2009, 6:e1000097.

10.1371/journal.pmed.1000097

7. Danielson ML, Bitsko RH, Ghandour RM, Holbrook JR, Kogan MD, Blumberg SJ: Prevalence of parentreported ADHD diagnosis and associated treatment among U.S. children and adolescents, 2016. J Clin Child Adolesc Psychol. 2018, 47:199-212. 10.1080/15374416.2017.1417860

8. Higgins JP, Altman DG, Gøtzsche PC, et al.: The Cochrane Collaboration's tool for assessing risk of bias in randomised trials. BMJ. 2011, 343:d5928. 10.1136/bmi.d5928

9. Sterne JA, Hernán MA, Reeves BC, et al.: ROBINS-I: a tool for assessing risk of bias in non-randomised studies of interventions. BMJ. 2016, 355:i4919. 10.1136/bmj.i4919

10. Kahathuduwa CN, Wakefield S, West BD, Blume J, Dassanayake TL, Weerasinghe VS, Mastergeorge A: Effects of L-theanine-caffeine combination on sustained attention and inhibitory control among children with ADHD: a proof-of-concept neuroimaging RCT. Sci Rep. 2020, 10:13072. 10.1038/s41598-020-70037-7

11. Kahathuduwa CN, Dhanasekara CS, Chin SH, Davis T, Weerasinghe VS, Dassanayake TL, Binks M: ITheanine and caffeine improve target-specific attention to visual stimuli by decreasing mind wandering: a human functional magnetic resonance imaging study. Nutr Res. 2018, 49:67-78. 10.1016/j.nutres.2017.11.002

12. Kahathuduwa CN, Dassanayake TL, Amarakoon AM, Weerasinghe VS: Acute effects of theanine, caffeine and theanine-caffeine combination on attention. Nutr Neurosci. 2017, 20:369-77. 10.1080/1028415X.2016.1144845

13. Haskell CF, Kennedy DO, Milne AL, Wesnes KA, Scholey AB: The effects of L-theanine, caffeine and their combination on cognition and mood. Biol Psychol. 2008, 77:113-22.10.1016/j.biopsycho.2007.09.008

14. Baba Y, Inagaki S, Nakagawa S, Kobayashi M, Kaneko T, Takihara T:Effects of daily matcha and caffeine intake on mild acute psychological stress-related cognitive function in middle-aged and older adults: a randomized placebo-controlled study. Nutrients. 2021, 13:1700. 10.3390/nu13051700

15. Yoto A, Motoki M, Murao S, Yokogoshi H: Effects of L-theanine or caffeine intake on changes in blood pressure under physical and psychological stresses. J Physiol Anthropol. 2012, 31:28. 10.1186/1880-6805$31-28$ 